Resona Jumal Ilmiah Pengabdian Masyarakat Vol. 1, No. 1 (2017) 1-5

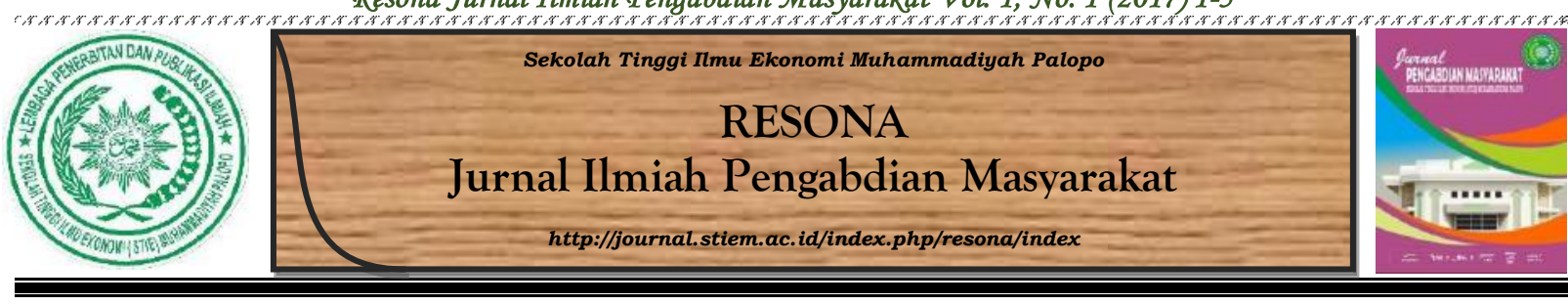

\title{
Pengabdian KKN-PPM di Desa Lagego Kecamatan Burau Kabupaten Luwu Timur
}

\author{
Sapar $^{1}$, Lanteng Bustami ${ }^{2}$, A. Hasbi Munarka ${ }^{3}$ \\ 1,2,3Sekolah Tinggi Ilmu Ekonomi Muhammadiyah Palopo
}

\section{INFO NASKAH \\ why why \\ Diserahkan \\ 22 November 2017 \\ Diterima dan disetujui \\ 26 Desember 2017 \\ , y,y,y,y,y,s,y,y,y,y,y,y,y,y,y,y,y,y,y,y,4}

\section{Kata Kunci:}

Pupuk organik

Kopi biji pepaya

Pengabdian

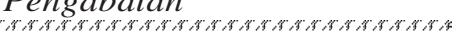

\begin{abstract}
ABSTRAK
ABSTRAK Tujuan progam KKN-PPM ini adalah peningkatan pengetahuan, sikap, dan keterampilan masyarakat tentang pertanian organik, peningkatan pengetahuan kewirausahaan, dan terkoordinirnya kegiatan kepemudaan (karang taruna) dan kewanitaan Desa Lagego. Target khusus progam ini berupa produksi pupuk organik, kopi biji papaya, dan jamur tiram yang berdampak pada penumbuhan jiwa entrepreneurship masyarakat Lagego, peningkatan wawasan dan pengetahuan tentang pertanian organik, kopi biji papaya, dan budidaya jamur tiram. Metode pelaksanaan progam KKN-PPM ini adalah pendampingan dan penyuluhan dalam bentuk pelatihan pembuatan pupuk organik, pelatihan pembuatan kopi biji papaya, dan pelatihan budidaya jamur tiram. Selain itu, juga dilakukan kegiatan pendukung berupa pertandingan 17 Agustus, pembinaan Taman Pendidikan Al-Qur'an (TPA) dan kegiatan majelis Ta'lim. Hasil kegiatan menunjukkan bahwa pelatihan dan pendampingan serta kegiatan pendukung acara pertandingan 17 Agustus, pembinaan TPA dan Majelis Ta'lim pada masyarakat Desa Lagego, Kecamatan Burau, Kabupaten Luwu Timur berdampak pada peningkatan pengetahuan, sikap dan keterampilan. Kegiatan pelatihan dan pendampingan dapat meningkatkan pengetahuan, sikap dan keterampilan masyarakat Desa Lagego.
\end{abstract}

\section{Pendahuluan}

Desa Lagego adalah salah satu desa yang terletak di Kecamatan Burau, Kabupaten Luwu Timur. Desa Lagego memiliki penduduk sebanyak 2.447 jiwa yang terdiri dari laki-laki 1.249 orang dan perempuan 1.198 orang, dan 530 KK. Mata pencarian warga Desa Lagego sebagian besar dari perkebunan, ladang, dan perikanan. Potensi yang dapat dikembangkan di Desa Lagego adalah perkebunan yaitu perkebunan kelapa sawit, perkebunan coklat, dan empang. Desa Lagego, Kecamatan Buaru, Kabupaten Luwu Timur juga terdapat penggilingan padi yang banyak menghasilkan arang sekam dan bekatul atau dedak, dimana arang sekam dan 
bekatul atau dedak ini juga digunakan sebagai campuran media dalam pembuatan pupuk organik. Selain itu, di sekitar Desa Lagego banyak dijumpai kotoran kambing dan ternak lainnya.

Sebagian besar masyarakat di Desa Lagego adalah petani/petambak selanjutnya sebagai pedagang. Keadaan mata pencaharian ini mendukung aktivitas pelatihan pupuk organik dimana di satu sisi diharapkan sebagai produsen pupuk organik dan di sisi lain yang memasarkannya.

Tanah adalah tubuh alam yang tersusun dalam bentuk profil. Tanah terdiri dari berbagai campuran mineral pecah lapuk dan organik pengurai sebagai lapisan tipis penutup permukaan bumi, serta menjamin tumbuhnya tumbuhan, hewan, dan manusia. Substansi tanah terdiri dari empat komponen utama yang mendukung kemungkinan hidupnya tumbuhan, yaitu bahan mineral, bahan organik, air, dan udara. Posisi dan keadaan komponen-komponen tersebut sangat menentukan kesuburan tanah atau penggunaan tanah untuk macam-macam usaha tani.

Pupuk adalah bahan yang ditambahkan ke dalam tanah untuk menyediakan unsur hara guna mendorong pertumbuhan tanaman, meningkatkan produksi, serta memperbaiki kualitasnya. Pupuk digolongkan berdasarkan pada sumber bahan yang digunakan, cara aplikasi, bentuk dan kandungan unsur haranya. Berdasarkan sumbernya terdapat dua jenis pupuk, yaitu pupuk organik dan pupuk anorganik.

Pupuk organik adalah pupuk yang berasal dari sisa-sisa tanaman, hewan, atau manusia seperti pupuk kandang, pupuk hijau, dan kompos baik berbentuk cair maupun padat. Sebagaimana Permentan Nomor: 28/PERMENTAN/SR.130/5/2009 menyatakan bahwa pupuk organik adalah pupuk yang sebagian besar atau seluruhnya terdiri dari bahan organik yang berasal dari tanaman dan/atau hewan yang telah mengalami proses rekayasa, dapat berbentuk padat atau cair yang digunakan mensuplai bahan organik, memperbaiki sifat fisik, kimia, dan biologi tanah (Hardjowigeno, 1995).

Berdasarkan hasil pengamatan terhadap beberapa masyarakat di Desa Lagego, Kecamatan Burau, Kabupaten Luwu Timur, maka diidentifikasi beberapa potensi kaitannya dengan pupuk organik, yaitu: (a) masyarakat Desa Lagego sebagian besar petani/petambak; (b) terbentuknya kepengurusan Badan Usaha Milik Desa (BUMD); dan (c) terbentuknya organisasi kepemudaan (karang taruna) dan organisasi kewanitaan Desa Lagego. Berdasarkan beberapa kenyataan tersebut di atas, maka diidentifikasi beberapa Permasalahan di Desa Lagego, Kecamatan Burau, Kabupaten Luwu Timur yaitu: (a) lemahnya pengetahuan masyarakat 
tentang pupuk organic; (b) pengurus BUMDES masih terkendala tentang pengetahuan kewirausahaan; dan (c) kegiataan kepemudaan (karang taruna)/kewanitaan belum terkoordinir dengan baik.

\section{Metode Pelaksanaan}

Metode Pelaksanaan program KKN-PPM dalam kegiatan pemberdayaan ini berupa pelatihan dan pendampingan pada aspek teknis maupun aspek manajemen dan pemasarannya, dengan materi pokok: (a) pelatihan pembuatan pupuk organik; (b) pelatihan pembuatan kopi biji papaya; (c) pelatihan budidaya jamur tiram; dan (d) kegiatan pendukung berupa perlombaan 17 Agustusan, pembinaan Taman Pendidikan Al-Qur'an (TPA), dan pembinaan Majelis Ta'lim.

\section{Hasil dan Pembahasan}

Program pengabdian KKN-PPM ini dilakukan dengan melalui tahapan sebagai berikut:

\section{Persiapan dan Pembekalan}

Materi persiapan dan pembekalan KKN-PPM yang diberikan kepada mahasiswa adalah sebagai berikut: (a) produksi pupuk organik, kopi biji papaya, dan jamur tiram; (b) pemasaran pupuk organik, kopi biji papaya, dan jamur tiram; (c) mengembangkan jiwa kewirausahaan; (d) membangun tim kerja yang efektif dan efisien; (e) teknik-teknik pemberdayaan dan penyuluhan masyarakat; dan (f) pupuk organik dari limbah pertanian/peternakan.

\section{Pelaksanaan}

Pelaksanaan program KKN-PPM ini adalah sebagai berikut: (a) pembekalan mahasiswa peserta KKN-PPM; (b) sosialisasi program KKN-PPM kepada masyarakat Desa Lagego dalam bentuk seminar program kerja; (c) penyiapan sarana dan prasarana yang mendukung pelaksanaan kegiatan; (c) penyiapan peralatan dan introduksi peralatan yang dirancang dan dilaksanakan oleh tim pengabdi; (d) peningkatan pengetahuan dan keterampilan mitra melalui pelatihan (penguatan jiwa entrepreneurship, pelatihan teknis pembuatan pupuk organik, pelatihan kopi biji pepaya, dan pelatihan budidaya jamur tiram); (e) operasionalisasi program KKN-PPM; dan (f) monitoring dan evaluasi program untuk menjamin keberlanjutan dan pengembangan program KKN-PPM.

Pelaksanaan kegiatan KKN-PPM ini terlaksana dengan baik melalui kerjasama dan partisipasi aktif dari mitra/masyarakat. Selain partisipasi sebagai kelompok sasaran atau 
peserta dalam pelatihan yang akan dilaksanakan pada program ini, mitra/masyarakat juga berpartisipasi dalam hal penyiapan alat dan bahan pengolahan yang tersedia di lokasi mitra/masyarakat.
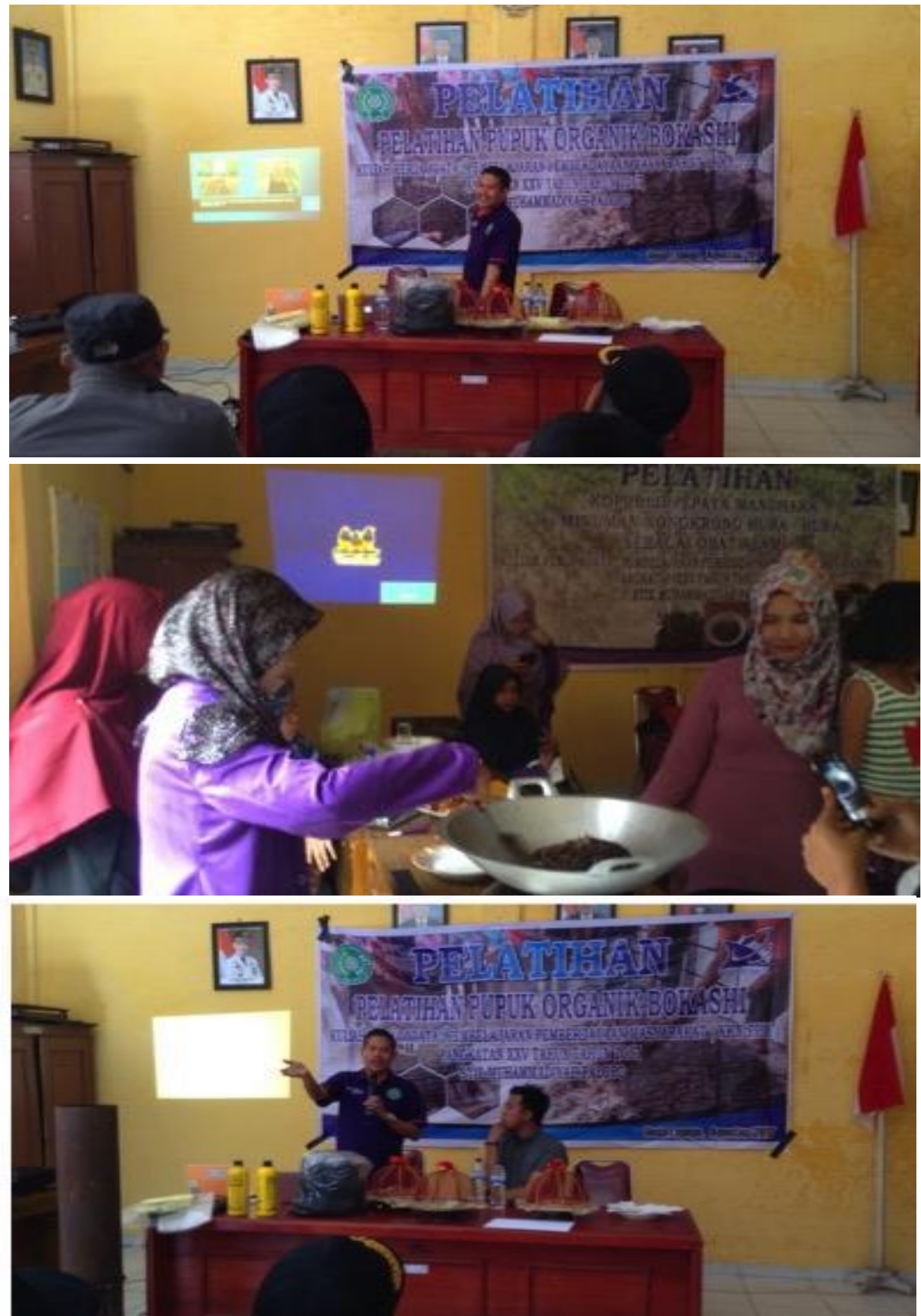

Gambar 1. Pelatihan Pembuatan Pupuk Organik, Kopi Biji Papaya, dan Jamur Tiram 


\section{Monitoring dan Evaluasi}

Setelah pelaksanaan kegiatan pengabdian KKN-PPM ini, maka untuk menunjang keberlanjutan program dilakukan monitoring dan evaluasi program. Kekurangan selama pelaksanaan pengabdian KKN-PPM dijadikan bahan evaluasi untuk penyempurnaan kegiatan berikutnya.

\section{Simpulan dan Saran}

Kesimpulan program KKN-PPM ini adalah pelatihan dan pendampingan tentang pupuk organik, kopi biji papaya, dan jamur tiram dapat meningkatkan pengetahuan, sikap, dan keterampilan masyarakat Desa Lagego sehingga menjadi produk andalan BUMDES Desa Lagego. Adapun saran dalam setelah melakukan program ini adalah Badan Usaha Milik Desa (BUMDES) dan beberapa kelompok masyarakat Desa Lagego perlu mendapat perhatian khususnya berupa pendampingan baik aspek teknis dan manajemen pupuk organik, kopi biji papaya, dan jamur tiram agar produksi terus berkelanjutan dan dijadikan sebagai salah satu produk unggulan BUMDES Desa Lagego, Kecamatan Burau, Kabupaten Luwu Timur.

\section{Daftar Pustaka}

Haryadi. 1982. Pemanfaatan Limbah Pertanian sebagai Bahan Baku. Yogyakarta: Fakultas Pertanian UGM.

Isnaini, M. 2006. Pertanian Organik. Yogyakarta: Kreasiwacana.

Musnamar, E.I. 2005. Pupuk Organik Padat: Pembuatan dan Aplikasi. Jakarta: Penebar Swadaya.

Musnamar, E.I. 2009. Pupuk Organik: Cair dan Padat, Pembuatan, Aplikasi. Jakarta: Penebar Swadaya.

Novizan. 2007. Petunjuk Pemupukan yang Efektif. Jakarta: Agromedia Pustaka.

Sutedjo, M.M. 2008. Pupuk dan Cara Pemupukan. Jakarta: Rineka Cipta. 